\title{
土中におけるジオテキスタイル水平ドレーン材の通水・透水性能
}

$\begin{array}{cccc}\text { 日本大学大学院 } & \text { 学生員 } & \text { ○椛澤 } & \text { 竜生 } \\ \text { 日本大学理工学部 } & \text { 正会員 } & \text { 巻内 } & \text { 勝彦 } \\ \text { 同上 } & \text { 正会員 } & \text { 峯岸 } & \text { 邦夫 }\end{array}$

\section{概要 :}

現地発生土である高含水比粘性土を用いての盛土の構筑や通常の土質構造物における浸透水の集排水 を目的とした対策工の中に, ジオシンセティックス(ジオテキスタイル, ジオコンポジット等)をドレー ン材として用いる工法がある。しかし通水性能と透水性能がそれぞれ異なるジオシンセティックスを土 中に敷設したとき地盤との関係においての排水メカニズムに関して,未解明な部分も少なくない。

そこで本研究では地盤内に水平に敷設したジオテキスタイル(不織布)をドレーン材として用いたと きの面内方向の通水性, 垂直方向の透水性について室内土槽試験を行い, 水頭, 上載圧, 土の種類の影 響について調べた結果を報告する。

キーワード: ジオテキスタイル, 水平ドレーン材, 通水性能, 透水性能, 透水試験

\section{Transmissivity and Permittivity of Horizontal Geotextile Drain Material in Soi 1 \\ by}

\author{
Ryusei KABASAWA, Katsuhiko MAKIUCHI \& Kunio MINEGISHI \\ (College of Science \& Technology, Nihon University)
}

Abstract:

Horizontal geosynthetic drain such as geotextile, geotextile-related product and geocomposite are employed for constructing of highly moistured clay embankment and drainage of seepage water in the existing embankment. The usage of the geosynthetic drain materials is being increased because of the shortage of natural filter sands.

In order to investigate fundamental properties of transmissivity (in-plane permeability) and permittivity (cross-plane permeability) of horizontal drain materials embedded in the embankment, a series of laboratory box permeability tests under different water heads and overburden pressures are conducted using a spunbonded geotextile, Toyoura sand and Kanto loam clayey soil.

It was found from the test results that there was a constant ratio of in-plane permeability to cross-sectional one, and the transmissivity was affected by the decrease in the thickness of geotextile under surcharge loads.

keyword:geotextile, horizontal drain, transmissivity, permittivity, permeability test 


\section{土中におけるジオテキスタイル水平ドレーン材の通水・透水性能}

\begin{tabular}{|c|c|c|}
\hline 日本大学大学院 & 学生員 & ○椛澤 \\
\hline 日本大学理工学部 & 正会員 & 巻内 \\
\hline 同上 & 正会員 & 峯岸 \\
\hline
\end{tabular}

\section{1.はじめに}

高含水比粘性土を用いての盛土構築や, その他 一般の土質構造物における浸透水の効果的集排水 を目的とした対策工法の中にジオシンセティック ス(ジオテキスタイル, ジオコンポジットなど)を ドレーン材として用いた工法がある。最近では良 質な自然のフィルター材が枯渇化していることも あり, ジオシンセティックスのドレーン材として の利用は高まるものと考えられる。シート状のジ オシンセティックスを地盤中に水平敷設した時, 通水性能と透水性能がそれぞれ異なるため, その 地盤特性との関係においての排水メカニズムの解 明は適切なドレーン材の選定に際して重要な意味 をもつ。

本研究では, 水平に敷設したジオシンセティッ クス(不織布)をドレーン材として用いたときの面 内方向の通水性, 垂直方向の透水性について室内 土槽試験を行い, 考察した。

\section{2. 試験方法と条件}

\section{2-1 水平ドレーン材の排水性能試験}

水平ドレーン材としてスパンボンド不織布 $\mathrm{S}-$ 300 (厚さ $3 \mathrm{~mm}$ ) を用いた。ドレーン材単体の面 内方向の通水性と垂直方向の透水性および地盤之 の関係を調べるために, 試料土に埋設した水平ド レーン材の排水性能を調べた。後者の場合は,『試 料土+ドレーン材』として一つの複合体と考えて の数值である。

試料土には, 高含水比粘性土である関東ローム $\left(\rho_{\mathrm{s}}=2.67 \mathrm{~g} / \mathrm{cm}^{3}, \mathrm{w}_{\mathrm{n}}=110 \%, \mathrm{w}_{\mathrm{L}}=143.7\right.$ $\left.\%, \mathrm{w}_{\mathrm{P}}=68.9 \%, \mathrm{I}_{\mathrm{P}}=74.8\right)$ を使用した。

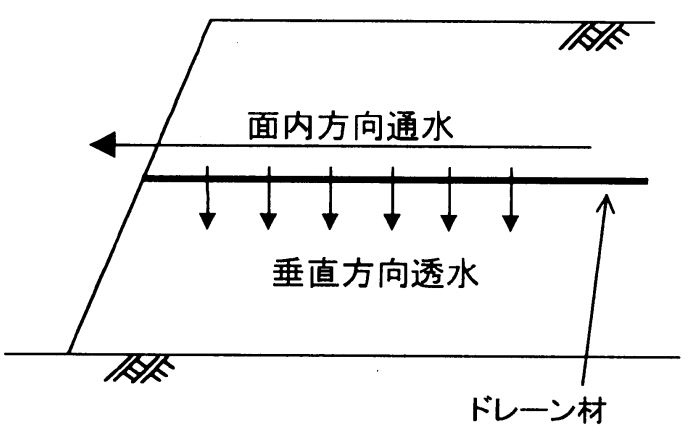

図-1 面内方向通水と垂直方向透水

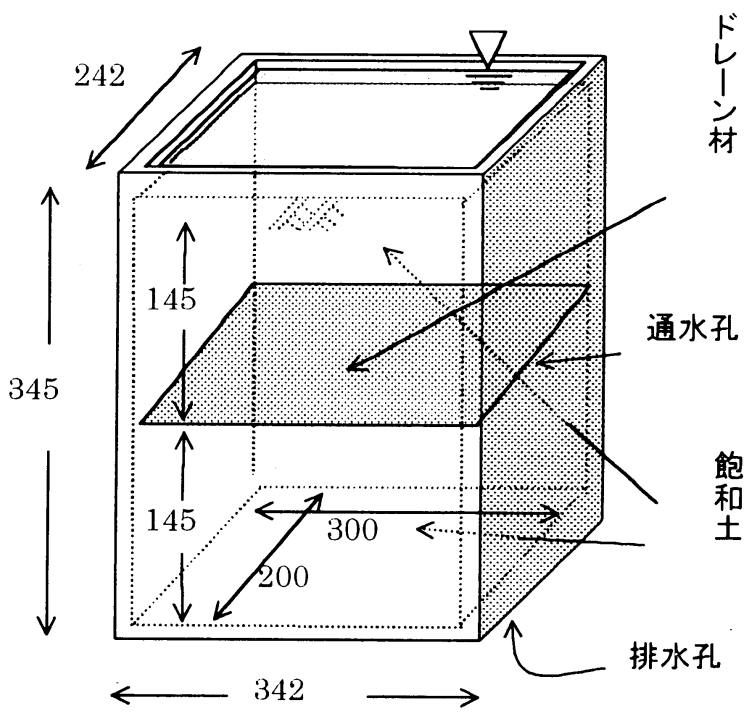

単位 : mm

図-2 室内土槽試験装置 
面内方向通水試験は, 試験装置にドレーン材を水平に敷設し, 動水勾配 i（水頭差／試料長さ） を0.1，0.2，0.5の3 種類と流量が安定した後，一定流量が得られるまでの時間を測定した。

垂直方向透水試験は, 網ふるいを二つ重站合わせたものを試験装置として用い, 上部ふるいの底 にドレーン材を敷設し, 水頭差を $1 ， 3 ， 5 \mathrm{~cm}$ に設定して上記と同様に一定流量の時間を測定し た。同様にして, 試料土を用いたときの透水性を調べるために土槽に試料を所定の密度で締め固め て入れ, 水頭差を同様に設定して試験を行った。

\section{2-2 室内土槽試験}

試料土として, 透水性の高い豊浦砂 $\left(\rho_{\mathrm{s}}=2.64 \mathrm{~g} / \mathrm{cm}^{3}\right)$, 透水性の低い関東ローム(排水性能 試験で用いた試料と同じ)の 2 種類を用いて行い, 図ー 2 に示す試験装置の中央部にドレーン材を 敷設した場合と無敷設の場合について試験を行った。各方向の集水量は土槽上部より水を注入し続 けた状態で試料土を飽和状態にし, 流量が安定した状態にしてから 5 分毎に面内方向の通水量と垂 直方向の透水量の測定を行った。

同様にして載荷重下の挙動を調べるために,ドレーン材を敷設した場合で, 上載圧力を $5 \mathrm{kPa}$ と $10 \mathrm{kPa}$ を載荷して試験を行った。この場合, 試料土には関東ロームを用いて行った。

\section{3. 試験結果および考察}

\section{3-1 面内方向通水性能試験結果}

ドレーン材のみの性能試験結果を表ー 1 に, 試料土+ドレーン材の性能試験結果を表ー 2 に示 寸。また, 各值を求める式を以下に示す。

$$
\begin{aligned}
& \mathrm{k}_{\mathrm{p}}=\mathrm{q}_{\mathrm{p}} /(\mathrm{i} \cdot \mathrm{A}) \\
& \mathrm{q}_{\mathrm{p}}^{\prime}=\mathrm{k}_{\mathrm{p}} \cdot \mathrm{T}_{\mathrm{g}} \cdot \mathrm{i} \\
& \left.\theta_{15}=(\mathrm{Q} \cdot \mathrm{L}) / \Delta \mathrm{h} \cdot \mathrm{W} \cdot \mathrm{t}\right) \eta_{\mathrm{t}}
\end{aligned}
$$

$\mathrm{k}_{\mathrm{p}}$ : 通水係数 $(\mathrm{cm} / \mathrm{s}), \mathrm{q}_{\mathrm{p}}$ : 通水量 $\left(\mathrm{cm}^{3} / \mathrm{s}\right), \mathrm{i}$ : 動水勾配, $\mathrm{A}$ : 通水面積 $\left(\mathrm{cm}^{2}\right), \mathrm{T}_{\mathrm{s}}$ : ドレーン 材の厚さ $(\mathrm{cm}), \mathrm{q}_{\mathrm{p}}^{\prime}$ : 通水能力 $\left(\mathrm{cm}^{2} / \mathrm{s}\right), \theta_{15}: 15^{\circ} \mathrm{C}$ における通水性能 $\left(\mathrm{s}^{-1}\right), \mathrm{Q}:$ 流量 $\left(\mathrm{cm}^{3}\right)$, $\mathrm{L}$ : 試料長さ $(\mathrm{cm}), \Delta \mathrm{h}$ : 水頭差 $(\mathrm{cm}), \mathrm{W}$ : 試料幅 $(\mathrm{cm}), \mathrm{t}$ : 測定時間 $(\mathrm{s}), \eta_{\mathrm{t}}$ : 水の温度補正係数

ドレーン材の面内方向の通水性能とは土の 透水係数とは異なるものであり, 単位時間で のドレーン材からの単位厚さを通過する流量 という物理量で表される。

水平ドレーン材の面内方向の通水能力（式 2 ) は,ドレーン材単体の場合では動水勾配が

\begin{tabular}{|c|c|c|c|} 
表 -1 ドレーン材の面内方向通水試験結果 \\
\hline 動水勾配 i & 0.1 & 0.2 & 0.5 \\
\hline 通水量 $\mathrm{q}_{\mathrm{o}}\left(\mathrm{cm}^{3} / \mathrm{s}\right)$ & 1.646 & 2.301 & 4.776 \\
\hline 透水係数 $\mathrm{k}_{\mathrm{p}}(\mathrm{cm} / \mathrm{s})$ & 2.744 & 1.917 & 1.592 \\
\hline 通水能力 $\mathrm{q}^{\prime}\left(\mathrm{cm}^{2} / \mathrm{s}\right)$ & 0.082 & 0.115 & 0.239 \\
\hline 通水性能 $\theta_{T}\left(\mathrm{sec}^{-1}\right)$ & 0.802 & 0.561 & 0.072 \\
\hline
\end{tabular}
高くなるとより排水量が増加する結果になっ た。 
ただし，図ー3を見ると，通水能力は増加 するに伴い通水性能は低下する傾向を示すこ とからドレーン材に排水限界があると考えら れる。

試料土に埋設したドレーン材の面内方向の 通水性を,ドレーン材単体の場合の通水能力 で比較すると平均で減少率が約 7 割と大きな 差異を生じている。試料土の試験中の透水係 数が $1.13 \mathrm{~cm} / \mathrm{s} \sim 5.40 \times 10^{-4} \mathrm{~cm} / \mathrm{s}$ と粘性 土としては低い值を示した。通水性能が大き く減少したのは, 水平ドレーン材が用いる試 料土の透水性に支配的影響を大きく受けてい るためと考えられる。

\section{3-2 垂直方向透水性能試験結果}

ドレーン材単体の時の性能試験結果を表一 3 に, 試料土に埋設したドレーン材の性能試 験結果を表一 4 に示す。また各值を求める式 を以下に示す。

$$
\begin{array}{ll}
\mathrm{k}_{\mathrm{n}}=\mathrm{q}_{\mathrm{n}} /(\mathrm{i} \cdot \mathrm{A}) & \cdots(4) \\
\mathrm{q}_{\mathrm{n}}^{\prime}=\mathrm{q}_{\mathrm{n}} / \mathrm{A} & \cdots(5) \\
\psi_{15}=\mathrm{Q} /(\Delta \mathrm{h} \cdot \mathrm{A} \cdot \mathrm{t}) \eta_{\mathrm{t}} \cdots(6)
\end{array}
$$

$\mathrm{k}_{\mathrm{n}}$ : 透水倸数 $(\mathrm{cm} / \mathrm{s}), \mathrm{q}_{\mathrm{n}}$ : 透水量 $(\mathrm{cm}$ $3 / \mathrm{s}), \mathrm{i}:$ 動水勾配, $\Delta h:$ 水頭差 $(\mathrm{cm})$, $A$ : 透水面積 $\left(\mathrm{cm}^{2}\right), \quad \mathrm{q}^{\prime}$ : 透水能力 $(\mathrm{cm} / \mathrm{s}), \phi_{15}: 15^{\circ} \mathrm{C}$ における透水性能 $\left(\mathrm{s}^{-1}\right), \mathrm{Q}$ : 流量 $\left(\mathrm{cm}^{3}\right), \mathrm{t}$ : 測定時間 $(s), \eta_{t}:$ 水の温度補正係数
表 -2 試料土+ドレーン材の面内方向通水試験結果

\begin{tabular}{|c|c|c|c|}
\hline 動水勾配 $\mathrm{i}$ & 0.1 & 0.2 & 0.5 \\
\hline 通水量 $\mathrm{q}_{\mathrm{p}}\left(\mathrm{cm}^{3} / \mathrm{s}\right)$ & 0.680 & 0.286 & 0.165 \\
\hline 透水係数 $\mathrm{k}_{\mathrm{p}}(\mathrm{cm} / \mathrm{s})$ & 1.134 & 0.239 & 0.055 \\
\hline 通水能力 $\mathrm{q}^{\prime}\left(\mathrm{cm}^{2} / \mathrm{s}\right)$ & 0.057 & 0.014 & 0.008 \\
\hline 通水性能 $\theta_{\Gamma}\left(\mathrm{sec}^{-1}\right)$ & 0.332 & 0.070 & 0.016 \\
\hline
\end{tabular}

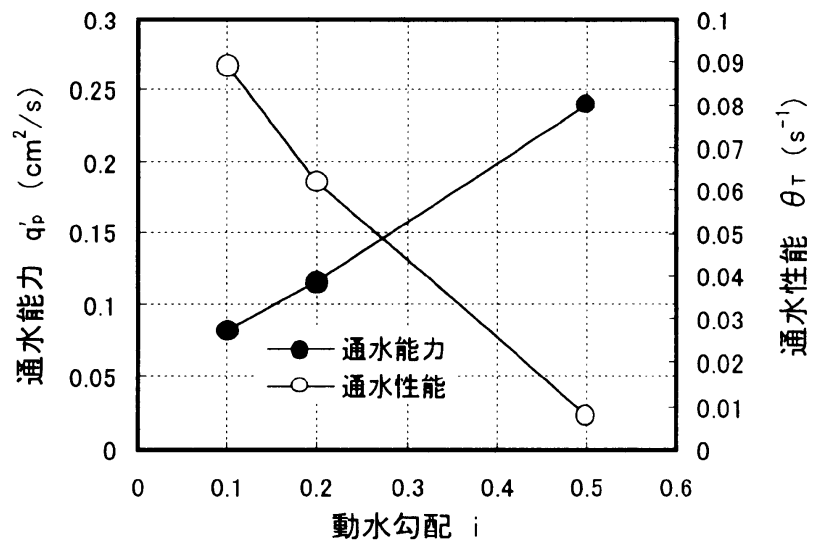

図一３ドレーン材の通水能力と通水性能
表ー3 ドレーン材の垂直方向透水試験結果

\begin{tabular}{|c|c|c|c|}
\hline 水頭差 $\Delta \mathrm{h}(\mathrm{cm})$ & 1 & 3 & 5 \\
\hline 透水量 $\mathrm{q}_{\mathrm{n}}\left(\mathrm{cm}^{3} / \mathrm{s}\right)$ & 3.190 & 32.57 & 67.890 \\
\hline 透水係数 $\mathrm{k}_{\mathrm{n}}(\mathrm{cm} / \mathrm{s})$ & 0.004 & 0.013 & 0.016 \\
\hline 透水能力 $\mathrm{q}_{\mathrm{n}}(\mathrm{cm} / \mathrm{s})$ & 0.013 & 0.133 & 0.269 \\
\hline 透水性能 $\psi_{\mathrm{T}}\left(\mathrm{sec}^{-1}\right)$ & 0.014 & 0.048 & 0.058 \\
\hline
\end{tabular}

表 -4 試料土+ドレーン材の垂直方向透水試験結果

\begin{tabular}{|c|c|c|c|}
\hline 水頭差 $\Delta \mathrm{h}(\mathrm{cm})$ & 1 & 3 & 5 \\
\hline 透水量 $\mathrm{q}_{\mathrm{n}}\left(\mathrm{cm}^{3} / \mathrm{s}\right)$ & 0.643 & 0.296 & 0.210 \\
\hline 透水係数 $\mathrm{k}_{\mathrm{n}}(\mathrm{cm} / \mathrm{s})$ & $0.60 \times 10^{-3}$ & $0.13 \times 10^{-3}$ & $0.54 \times 10^{-4}$ \\
\hline 透水能力 $\mathrm{q}_{\mathrm{n}}(\mathrm{cm} / \mathrm{s})$ & $1.98 \times 10^{-3}$ & $1.27 \times 10^{-3}$ & $0.09 \times 10^{-3}$ \\
\hline 透水性能 $\psi_{\mathrm{T}}\left(\mathrm{sec}^{-1}\right)$ & $2.16 \times 10^{-3}$ & $0.46 \times 10^{-3}$ & $0.20 \times 10^{-3}$ \\
\hline
\end{tabular}

図ー3 ドレーン材の通水能力と通水性能

図ー 4 に示すように, 垂直方向の透水能力と透水性能はともに水頭差の増加に伴い増加する傾向 を示した。ただし, 水頭差が $3 \mathrm{~cm}$ 付近から増加が緩慢になっている。これより,垂直方向の透水 性にも面内方向の通水性と同様に排水限界透水性能があると考えられる。

試料土+ドレーン材の垂直方向の透水能力, 透水性能は, ドレーン材単体の場合と比較して, 試 
料土に埋設したドレーン材の通水性能と同様に大きく低下しており, 透水性能は約 7 割近い減少率 を示す結果になった。これも試料土の透水係数に大きく依存していると考えられ，土中に敷設した ジオテキスタイルドレーン材は, 使用する地盤材料の透水係数に大きく左右される。

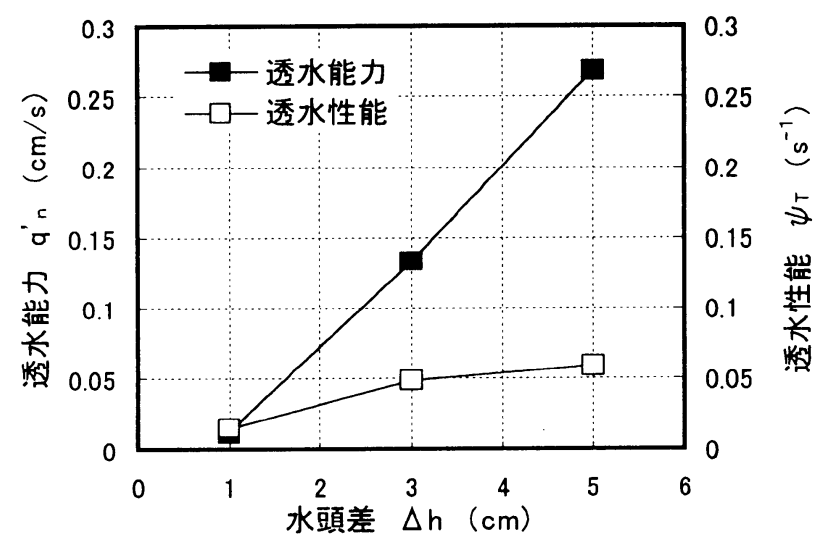

図-4 ドレーン材の透水能力と透水性能

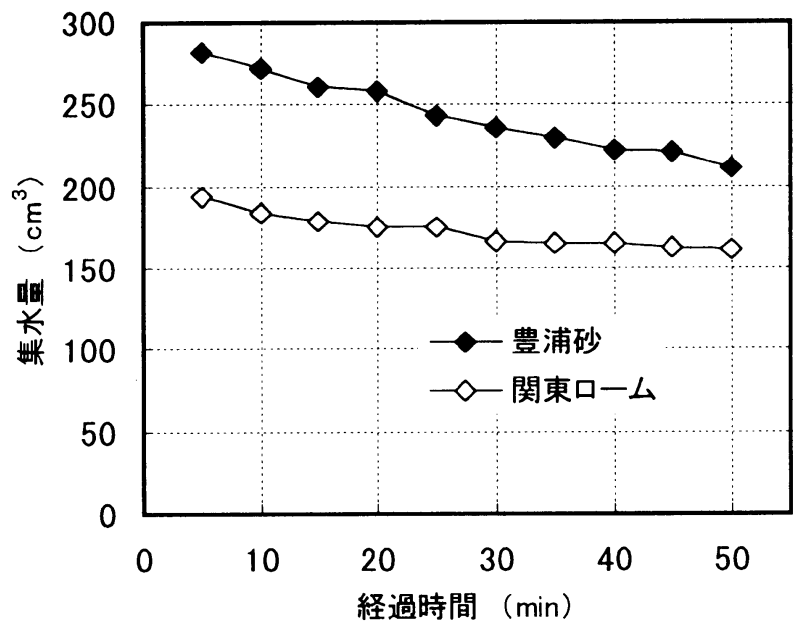

図－5 ドレーン材敷設時の土槽底部からの集水量

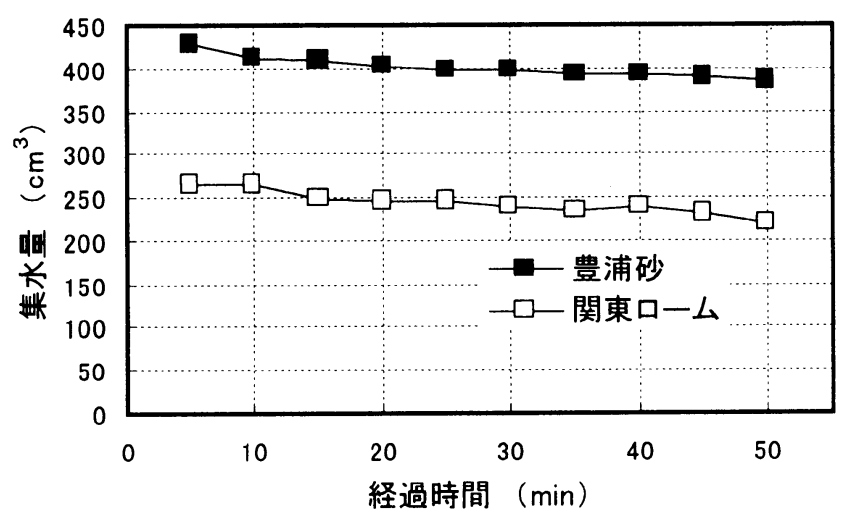

図一 6 試料土のみの土槽底部からの集水量

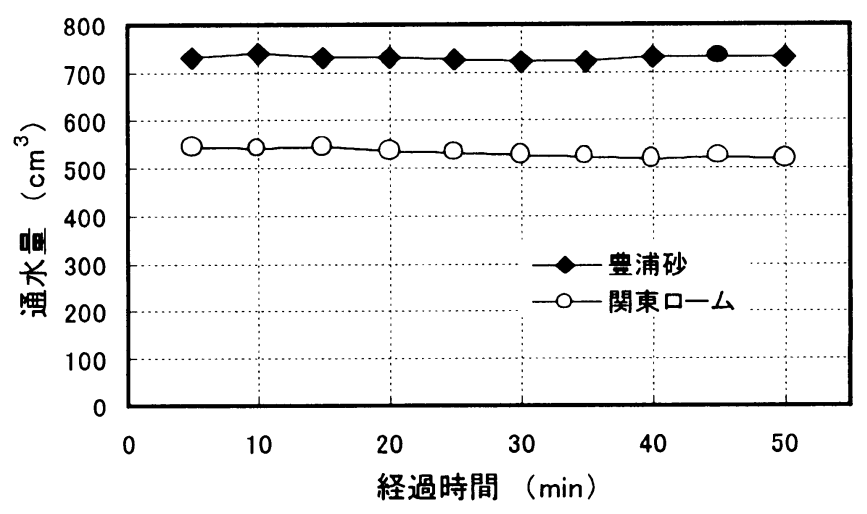

図一 7 ドレーン材敷設時の面内方向通水量 
ることが可能であることが示唆される。

\section{3-3-2 載荷重の影響}

載荷条件下の面内方向の通水量を図 -8 に, 垂直方向の集水量を図一 9 に示す。面内 方向の通水量は載荷重が大きくなるにした がって減少することがわかる。また垂直方 向の透水量は, 面内方向の通水量と比較し て若干安定した挙動を示している。荷重が 加わることによって, 土が圧密されること による透水係数の低下とドレーン材の厚さ の減少，およびドレーン材内に土粒子が侵 入しやすくなることによっての通水量の低 下，すなわち通水面積の減少を招くと考え られる。これらの結果より,載荷重は面内方 向の通水性には大きく影響を及ぼすが, 垂 直方向の透水性には影響が少ないと考えら れる。

また，荷重を加えた場合にも面内方向の 通水量と垂直方向の透水量には無載荷の場 合と同様の比率 ( $3: 1)$ を示したことから, 載荷時においても先述のことがいえる。

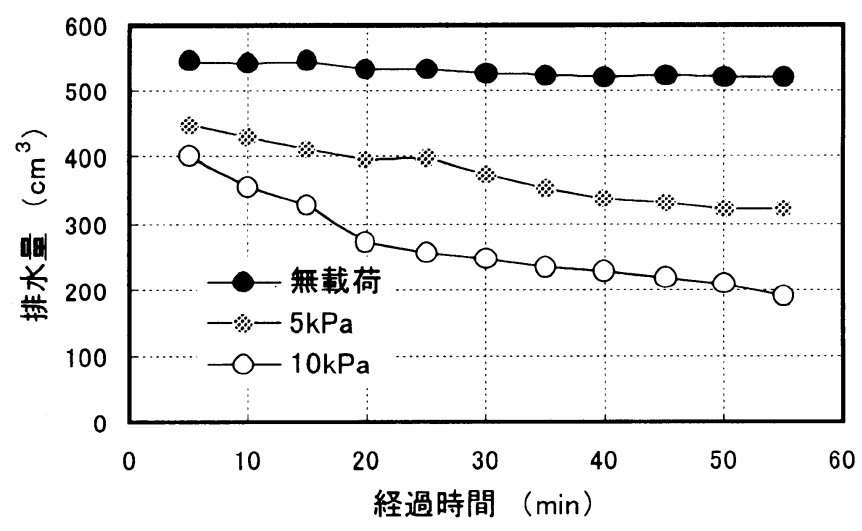

図一 8 載荷時と無載荷の面内方向通水量

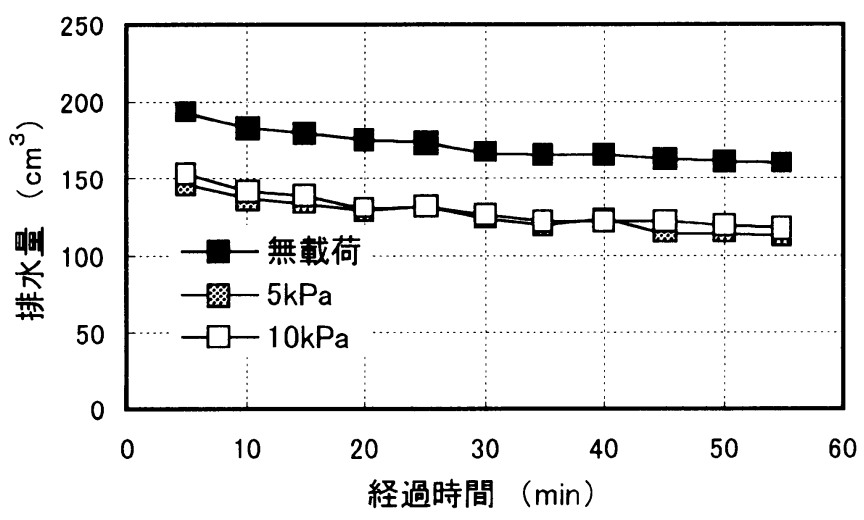

4.まとめ

図-9 載荷時と無載荷の底面からの集水量

本研究の範囲内で得られた結果をまとめると以下のようになる。

1 ) ジオテキスタイル水平ドレーン材を地盤内に敷設することによって, 高い排水効果が認めら れた。

2 ) ジオテキスタイル水平ドレーン材の面内方向の通水性, 垂直方向の透水性には, 通水・透水 能力を上げても排水限界がある。

3 ) ジオテキスタイル水平ドレーン材の面内方向の通水量と, 垂直方向の透水量には一定の割合 があり,試料土の種類による影響をほとんど受けない。

4 ) ジオテキスタイル水平ドレーン材の通水性は, 上載圧力によるドレーン材の厚さの減少によ り, 排水効果が減少しやすい。

今後は面内方向と垂直方向の排水性能を同時評価化可能な試験方法の開発と,ドレーン材の厚さ の減少, 目詰まりなどによる排水性の低下に関して,さらに基礎的な試験を行う必要がある。

【謝辞】本研究を行うにあたり, 本学学生の村上瓦, 小松智子両君の協力を得たことを記してここ に謝意を表します。 